\title{
Health Status of Boars Used in Reproduction
}

\author{
Dragan ROGOŽARSKI ${ }^{1}$, Jovan BOJKOVSKI ${ }^{2}$, Nataša PROKIĆ ${ }^{2}$, Teodora VASILJEVIĆ ${ }^{3}$ \\ ${ }^{1}$ Veterinary-specialistic institute Požarevac, Serbia, ${ }^{2}$ Faculty of Veterinary Medicine, \\ University of Belgrade, Belgrade, Serbia, ${ }^{3}$ Patent Co, Belgrade, Serbia \\ ${ }^{*}$ Corresponding author e-mail: bojkovski@vet.bg.ac.rs \\ Bulletin UASVM Veterinary Medicine 71(2) / 2014, \\ Print ISSN 1843-5270; Electronic ISSN 1843-5378 \\ DOI:10.15835/buasvmcn-vm: 10694
}

\begin{abstract}
Breeding and exploitation of boars at commercial farms aim at producing semen doses for internal use. The lifetime of boars and hence the length of their operation on farm, to a large extent depend on their health. Control of boars' health status; quality control of semen intended for artificial insemination by supervision of the entire process: sperm collection, quality assessment and making of insemination doses; monitoring of boars' living conditions: housing, microclimate, feed, the attitude of employees. Our experiment included 40 boars from one farm of commercial type in Serbia. All boars had been imported from the European Union at age of 6 months and represents genetically superior animals. Health status was observed daily, during one year; in the same time period, semen quality assessment was done once per week (at each collection). After one year, from the total of 40 boars used in reproduction, seven of them showed signs of lameness. Three of them were excluded from further exploitation because of inability to jump on phantom. Initial problems often occur after first jump, as a result of poor femur cartilage ossification. In some cases, lameness appeared as a result of a severe infection which involved pads and hooves on hind legs. None of affected boars have decrease in semen quality. In conclusion, health check-up of breeding boars is required to be a complex process within the implementation of health care on commercial farms. Problems of the locomotor system occupy particular attention. Accordingly, implementation of specific, defined procedures within the boars' medical supervision need to exist, with the aim to reduce boar exclusion from the exploitation process and thus decrease economic losses at farms.
\end{abstract}

Keywords: boar, health, lameness, reproduction

\section{INTRODUCTION}

Boars used for obtaining semen for artificial insemination in commercial farms are subjected to certain measures of health control. This primarily relates to methods of immuno-prophylaxis and regular serological tests for early detection of the presence of specific viral and/or bacterial antibodies. The dynamics and type of necessary procedures are prescribed by the OIE and, if necessary, amended by current legislation on health protection of certain state. The goal is to have disease-free boars to ensure good health of the entire herd. Once to twice per year, beside regular analysis of boars' serum, it's necessary to do bacteriological examination of fresh semen and prepuce, as well as smears from the environment in which boars live (the pens' floor, walls, feeders, drinkers).
Beside infective agents, one of the most important health problems within boars in intensive farm production are locomotor disorders (Muirhead et al., 2002). In majority of cases, lameness appears in smaller or higher degree (Sims LD and Glastonbury JRW 1996; Schwartz et al., 2004; Bojkovski et al., 2013). Lameness is also a cause of too early culling for boars due mainly to an inability to mount phantom during semen collection. The consequences are the increased costs of replacement and overwork of the remaining boars, leading to lower conception rates.

\section{MATERIALS AND METHODS}

Our study included 40 boars (Landrace and Yorkshire) from one farm of commercial type in Serbia. All boars had been imported from the 
European Union at age of 6 months and represents genetically superior animals. Health status was observed daily, during one year, starting from the day when they arrived in quarantine. During the quarantine period they were subjected to all necessary analyzes and taught to use phantom. At age of 8 months, they were introduced into intensive semen production. Routine semen quality assessment was done once per week (at each collection) and included measuring of semen volume, sperm motility, concentration per $\mathrm{ml}$ and total sperm count. Morphology of boar spermatozoa and bacteriological examination of semen were done at the first collection and then monthly, for the next 10 months.

\section{RESULTS AND DISCUSSIONS}

During one year, from the total of 40 boars used in reproduction, seven of them showed signs of lameness in different time periods. After adequate therapy treatment which involved local therapeutics and animal's resting, four boars were healed and returned to exploitation. None of affected boars have decrease in semen quality. Three boars were excluded from further exploitation because of inability to jump on phantom. Initial problems often occur after first jump, as a result of poor femur cartilage ossification. In some cases, lameness appeared as a result of a severe infection which involved pads and hooves on hind legs.

\section{Locomotor disorders}

The general effect of lameness is pain and suffering for the animal. Lameness can result from damage to any of the structures involved in locomotion including the bones, muscles, tendons, nerves and blood supply of the shoulder, hock, stifle, foot, toe or hoof. This leads to reduced mobility resulting in an inability to compete with pen mates for feed, water and space and interference with mating/using of phantom. In all types of pigs, lameness leads to increased veterinary costs and extra management requirements. There are four main causes of pig lameness: genetic, congenital, physical injury and infection.

Genetic cause of leg weakness isn't common in nowadays, still there is some evidence thatselection for faster growth has increased the problem. It is thought that growth and development of the bone does not keep up with muscle deposition, resulting in an increased susceptibility to injury. Defects in conformation, e.g. straight legs, uneven claws, may also lead to lameness.

The major congenital cause of lameness is splay-leg in sucking piglets. This condition is complex and not fully understood. Thus it has proved difficult to incorporate its eradication into breeding programs. It appears that occurrence of splay-legs increases with litter size and that males are twice as likely to be affected as females. As well, breed can be an important factor with piglets from Landrace and Pietrain sows in particular having a higher incidence than Large White.

Physical injuries mostly occur because inappropriate or poorly maintained floors. The effects are either wounds directly to the foot or damage to the joints, ligaments or muscles caused by pigs slipping on the floor surface. Arthritis, originated as a result of mechanical lesion (physical injury), is a pathological change on articular cartilage with secondary ossifying process of the periosteum and synovial membranes of joints (Ivetić et al. 2007; Šamanc, 2009; Bojkovski et al., 2012). Fractures are not always obvious. Fighting and sexual behavior (mounting) within a group of pigs can lead to an increase in the incidence of injuries in general, including those leading to lameness, particularly if the floor is in poor condition.

Infections occur due to bacteria which enter into a wound after physical injury, resulting in swollen joints and abscesses. Arthritis caused by Mycoplasma hyosynoviae, acute or chronic erysipelas can cause an incapacitating lameness. Polyarthritis and polyserositis caused by $M$. hyorhinis are seen occasionally. Susceptible, stressed adult pigs can succumb to M. hyorhinis with a higher fever and a more severe lameness than is seen in nursery pigs. Boars may develop scrotal edema and discomfort, potentially rendering them temporarily unfit for breeding.

At the beginning of a process, lameness can be diagnosed only during very careful clinical examination. The daily observation of boars must include the identification of any leg or foot problems. Pigs must be made to move around the pen, as lameness will not be seen if they are lying down. Lameness leads to atrophy of muscle tissue because suffering animal is attempting to save limb due to pain. Testing is done by observing lame animal towards moving and walking over obstacles whereby the diseased limb is compared 
with the adjacent limb. Each part of limbs with signs of abnormalities needs to be thoroughly examined. All injuries need to be checked and determinate if there is: a pain, swelling and whether it is maintained the flexibility of joint/s. The nature and behavior of pigs complicates this manner of inspection, so during the examination, veterinarian need to be careful and patient, look for the cause of the disease and consider the existence of indications to expand. All components of muscle-skeletal system must be taken into consideration when diagnosis is making. Accurate diagnosis is important in determining the cause, prognosis, treatment and prevention (Tadić et al., 1976). Nowadays, ultrasonography is a very useful tool for assessment of severe disease cases. Imaging methods such as radiology can be used in evaluation of fractures and other mechanical lesions, but it's expensive and that's why rarely used today. After making of relevant diagnosis, it's crucial to begin treatment as soon as possible.

Based on our previous experience, we concluded that most of the problems of boar locomotor system on farms occur as a result of inadequate accommodation space. All floors must provide adequate grip to prevent slippage whilst not causing physical injury or excessive abrasion to the feet or legs. All floor surfaces become increasingly slippery when they are wet or covered in manure. Surfaces should be kept dry either by good drainage or by the use of bedding to soak up the liquid. They should also be capable of being thoroughly cleaned and disinfected to prevent the build-up of disease organisms. The appropriate grade of mortar needs to be used in the surface screed to resist the corrosive effect of urine and certain liquid by-product feeds as well as the frequent use of the power washer.

Slatted floors are not recommended because they cause more injuries than bedded pens and therefore are less acceptable from a welfare point of view. Bedding has a positive benefit in terms of lameness due to its physical cushioning effect and should be used wherever possible. Bedded areas should always be kept as dry as possible as continuous contact with wet bedding can lead to a softening of foot tissues predisposing the foot to damage and bruising which can in turn allow infection to enter the foot.

The treatment of lameness in boars is carried out after setting the correct diagnosis and determination of the primary cause. Techniques such as foot bathing and paring may prove helpful for severe cases of lameness. Paring should be carried out by a skilled stockperson or veterinary surgeon. Where lameness does occur, the pen should be examined for any rough or sharp edges that could have caused injury and repairs carried out as necessary.

For the treatment of mechanical lesions it's recommended to use oxytetracycline in spray and for the treatment of arthritis regularly is used ichtiol-camphor. Mechanical lesions and arthritis may be treated with parenteral antibiotics, corticosteroids and analgesics. Use of corticosteroids should be limited because it's immunosuppressive effect, as well as a negative effect on the quality of sperm. If there is a suspicion on infectious arthritis, it is necessary to isolate a pathogen agent and implement an effective therapy according to antibiogram (Bojkovski et al., 2013).

Treated animals acquired particular attention and special living conditions. All boars need to be housed separately in warm, draught-free pens with dry deep bedding. The floors of these pens should be dry, provide adequate grip and be free of steps and rough edges. It is essential to ensure that adequate feed and water are supplied and that the pigs can reach them.

In young healthy boars as a form of prevention may be recommended lubricating grease for hoof care in order to help hooves and pads to timely become harden before animal get on its weight.

\section{Infectious agents in boar semen}

There are a large number of pathogens, both bacterial and viral etiology, which can be found in boars' semen and transmitted to a large number of recipient animals. The main concerns arise when the health status of boars is not controlled, and when hygiene of semen collection is neglected. For boars from AI Centers the risk is even greater, considering that only one boar can produce 20-50 doses weekly. The number of semen doses produced and the area in which they are distributed makes AI centers a major potential source of infection. Practices such as pooling semen from multiple boars exacerbate the health risks to recipient farms (Pinart E. and Puigmule M., 2013).

Maximum efforts must constantly be directed to maintain a high health status at Center for 
artificial insemination through the purchase of boars whose disease-free health status has been verified. The implementation of quality assurance in these farms should be a priority. Centers for artificial insemination should be officially controlled, and veterinary services' certification against transmissible diseases (pseudorabies, CSF, ASF, etc.) may be required.

Viral shedding through semen has been well-documented in both experimentally and naturally infected boars. Most systemic viruses can be excreted into the semen, which can be a source of transmission of Aujeszky's disease virus, parvovirus, CSF virus and PRRS virus. Regular bacteriological examinations of row semen are needed because some specific bacterial pathogens, including brucellosis and leptospirosis, are shed in semen, but most bacterial contaminants of semen are from fecal/environmental material. Appropriate hygiene during semen collection and distribution is therefore of primary importance, together with routine screening of boars for infections known to be spread by semen.

Employed workers on pig farms must be aware of their own potential role in the spread of disease, as they have physical contact with pigs - including those that are clinically affected - in their daily work. Service providers and intermediaries, such as pig transporters, technicians and veterinarians, may be required to visit several farms on the same day, thereby increasing the risk of disease spread; equally problematic is when workers at pig farm or their households keep pigs of their own.

Veterinary authorities should plan regular checks of Artificial Insemination facilities and practices. Traceability and quality control of the semen doses must be constant (FAO/OIE, 2010).

\section{farms}

Importance of biosecurity measures on

In order to maintain health status of boars and therefore the wholeherd, it is important to establish and follow biosecurity protocol. Biosecurity is defined as the implementation of measures that reduce the risk of disease agents being introduced and spread. It requires that people adopt a set of attitudes and behaviors to reduce risk in all activities involving domestic, captive/exotic and wild animals and their products (FAO/OIE/World Bank, 2008). Biosecurity measures should be used to avoid the entry of pathogens into a herd or farm (external biosecurity) and to prevent the spread of disease to uninfected animals within a herd or farm and to other farms, when the pathogen is already present (internal biosecurity) (Stanković et al., 2008, 2009).

The three main elements of biosecurity are: segregation, cleaning and disinfection. Segregation measures include controlling the entry of pigs from outside farms; implementing quarantine for newly purchased animals which should be kept for a minimum of 30 days in a quarantine pen; limiting the number of sources of replacement stocks; fencing a farm area and controlling access for people, as well as birds, bats, rodents, cats and dogs; maintaining adequate distances between farms; providing footwear and clothing to be worn only on the farm; and using an all-in-all-out management system. Cleaning by high-pressure and low-pressure washers enable removing of visible dirt (from buildings, vehicles and equipment) will remove most of the contaminating pathogens. Disinfection, as a final step, when properly applied, will inactivate any pathogen that remains on materials that have already been thoroughly cleaned.

The required biosecurity level on pig farms should be the result of logical thinking and timely taken action in that particular environment and epidemiological situation; with recognition of specific threats from environment and critical points in the production process. It is now known that the biosecurity, welfare, good manufacturing practices and risk analysis at critical control points are very important elements in intensive pig production, and it is therefore necessary to introduce them into production on commercial farms. Biosafety plans are critical in the prevention of diseases and adverse situations and they are necessary for performance improvement (Uhlehoop, 2007). Necessity is to make plans for emergency situations in real live production, with the aim of faster response to adverse events and timely continuing production (Valčić, 2007; Bojkovski et al. 2010).

\section{CONCLUSION}

Health control of breeding boars should be a complex process in furtherance of health protection measures on commercial farms.

Particular attention should be dedicated to problems with the locomotor system through implementation of defined procedures within 
the health surveillance of boars in service. The aim is reducing of boars' exclusion from the manufacturing process because it produces a significant economic damage to farms.

It is necessary to ensure that all boars that come to the farm originated from pathogen-free herd and the application of good biosecurity measures allow to remain so.

Acknowledgement: This article is part of a projects funded by the Ministry of Education, Science and Technological Development of Republic of Serbia, TR31071 and TR37015.

\section{REFERENCES}

1. Bojkovski, J., Vasiljević, T., Vasić, A., Zdravković N. Stojanović D., Rogožarski D. (2013). Animal health control of pigs on commercial farm. Proceedings of the 10th International Symposium „Modern Trends in Livestock Production", October 2-4, Hotel Park, Beograd, 713-722.

2. Bojkovski, J., Savić B., Relić R., Delić.N., Rogožarski, D., Petrujkić T., (2012). Locomotor system of pigs as a health problem in sows and boars, Proceedings of the first international symposium on animal science, Book II, November 8-10, Belgrade, Serbia.

3. Bojkovski, J., Relić, R., Hristov S., Stanković, B., Savić, B., Petrujkić T., (2010). Contribution to knowledge of health, reproduction, biosecurity and ecological problems in intensive pig production Bulletin UASVM, Veterinary Medicine, 67(2), pp.37-39. UASMV ClujNapoca, Symposiums "The $9^{\text {th }}$ International Symposium "Prospects for the 3rd millennium agriculture" pp. 1-5.

4. FAO/OIE/World Bank. (2008). Biosecurity for highly pathogenic avian influenza. Issues and options. Rome. 73 pp.

5. FAO/OIE. 2010. Good practices for biosecurity in the pig sector. Issues and options in developing and transition countries. Fao Animal Production and Health paper, No.169. Rome.

6. Ivetić V., Žutić B., Savić, B., Pavlović; I., Milošević B., Valter D. (2007). Atlas bolesti svinja, Naučni institut za veterinarstvo Srbije, Beograd.

7. Murihead MR, Alexander TJL (2002). Managing pig health and the treatment of disease. Enterpries, Shefield.

8. Pinart E., Puigmule M. (2013). Factors affecting boar reproduction, testis function and sperm quality. In S. Bonel \& I. Casas \& W.V. Holt \& M. Yeste (Eds),. Boar reproduction: fundamentals and new biotechnological trends (109-205), Springer.

9. Schwartz KJ (2004). Swine disease manuel, $3^{\text {rd }}$ edition. American Association of Swine veterinary, Perry.

10. Sims LD, Glastonbury JRW(eds.) (1996). Pathology of pig. Pig research and development. Corporation, Australia.

11. Stanković B., Hristov S., Petrujkić T., TodorovićJoksimović Mirjana, Davidović Vesna, Bojkovski J. (2008). Biosigurnost na farmama svinja u svakodnevnoj praksi, Biotehnology in animal husbandry, vol. 24, str. 601-608.

12. Stanković B., Hristov S., Valčić M., Petrujkić T., Bojkovski J. (2009). Standardi dobrobiti biosigurnosti na farmama goveda i svinja. 8. Kongres Veterinara Srbije sa međunarodnim učešćem. Zbornik referata, str. 67.

13. Tadić M., Mišić B., Štaljonić N., Petrović B. (1976). Dijagnostika oboljenja lokomotornog sistema svinja, Veterinarski glasnik br 1, str.77-80.

14. Uhlehoop E. (2007): Bisicurity planning for livestock farms. Dobrobit životinja i biosigurnost na farmama, monografija Poljoprivredni fakultet, Zemun, 227-237.

15. Valčić M. (2007): Osnovni kriteriujumi i principi pripreme nacionalnih planova ukontroli i suzbijanju i iskorenjivanju zaraznih bolesti „Dobrobit životinja i biosigurnost na farmama, monografija, Poljoprivredni fakultet Zemun, str. 239-250.

16. Šamanc H. (2009). Bolesti svinja, Naučna KMD, Beograd. 